\title{
Potensi Ekstrak Etanol Daun Kelor (Moringa oleifera L.) dalam Menurunkan Kadar Asam Urat Tikus Putih
}

\section{Potential of Moringa (Moringa oleifera L.) Leaves Ethanol Extract in Reducing Rat Uric Acid Levels}

\author{
Bayu Putra, Rizqi Nur Azizah*, Andi Clara \\ Fakultas Farmasi Universitas Muslim Indonesia Makassar \\ Kampus II, Jl. Urip Sumihardjo Km. 5 Makassar, Sulawesi Selatan \\ Kontak*: rizqi.azizah@umi.ac.id
}

\begin{abstract}
ABSTRAK
Daun kelor (Moringa oleifera L.) memiliki potensi yang diduga dapat menurunkan kadar asam urat tikus putih (Rattus norvegicus). Penelitian ini bertujuan untuk menentukan dosis ekstrak etanol daun kelora yang dapat menurunkan kadar asam urat tikus putih. Penelitian ini menggunakan 15 ekor tikus putih yang dibagi menjadi 5 kelompok. Kelompok I sebagai kontrol negatif yang diberikan jus hati ayam dan kalium oksonat $250 \mathrm{mg} / \mathrm{kgBB}$, kelompok II sebagai kontrol positif yang diberikan allopurinol $5 \mathrm{mg} / \mathrm{kgBB}$, dan kelompok III, IV, dan V sebagai kelompok perlakuan yang diberikan ekstrak etanol daun kelor dengan dosis 70, 140, dan $280 \mathrm{mg} / \mathrm{kgBB}$ selama 7 hari. Berdasarkan pengukuran kadar asam urat akhir didapatkan ekstrak etanol daun kelor dapat menurunkan kadar asam urat tikus putih.
\end{abstract}

Kata kunci: Asam Urat, Daun Kelor (Moringa oleifera L.)

\begin{abstract}
Moringa oleifera L. Leaves is assumed to reduce urid acid levels in white rats (Rattus norvegicus). The research aimed to determine the dose of Moringa leaves that reduced uric acid levels in white rats. It used 15 rats that divided into 5 groups. Group I was a negative control that given chicken liver juice and potassium oxonate 250 $\mathrm{mg} / \mathrm{kgBW}$. Group II was a positive control that given allopurinol $5 \mathrm{mg} / \mathrm{kgBW}$. Group III, IV, and V were given ethanol extract of Moringa leaves at 70,140, and $280 \mathrm{mg} / \mathrm{kgBW}$ for 7 days. The data showed that the ethanol extract of Moringa leaves at 70, 140, and $280 \mathrm{mg} / \mathrm{kgBW}$ had the potency to reduce rat uric acid levels.
\end{abstract}

Keywords: Uric Acid, Moringa leaves (Moringa oleifera L.)

\section{PENDAHULUAN}

Asam urat merupakan produk akhir dari metabolisme purin yang terjadi di dalam tubuh manusia. Asupan purin dalam tubuh berasal dari makanan yang dikonsumsi, baik yang berasal dari hewani maupun nabati. Asam urat sebagian besar berasal dari metabolisme nukleotida purin endogen, Guanylic Acid (GMP), Inosinic Acid (IMP), \& Adenylic Acid (AMP). Reaksi ini dibantu oleh suatu enzim yang disebut xanthine oxidase. Enzim tersebut berasal dari ginjal dan usus sehingga dapat mengubah hypoxanthine dan guanine menjadi xanthine. Jika terjadi gangguan pada ginjal maka asam urat dalam tubuh terutama darah akan meningkat atau disebabkan oleh tingginya asupan purin dalam makanan (Silbernagl \& Lang, 2000; Misnadiarly, 2007; Herliana, 2013). Gangguan ini disebut hiperurisemia 
yang dapat memicu terjadinya nefrolitiasis, dan juga terbentuknya kristal seperti jarum pada jaringan tubuh yang mengakibatkan terjadinya bengkak dan nyeri sendi yang berkembang menjadi gout arthritis (Suhendi, Nurcahyanti, Muhtadi, \& Sutrisna, 2011; Cendrianti, Muslichah, \& Ulfa, 2014).

Salah satu tanaman yang diduga dapat memberikan efek terapi dalam menurunkan kadar asam urat adalah daun kelor. Tanaman ini banyak dimanfaatkan oleh masyarakat umum terutama di Indonesia. Daun kelor banyak digunakan sebagai obat tradisional untuk menyembuhkan beberapa penyakit medis maupun non-medis. Senyawa kimia yang terkandung dalam daun kelor antara lain tanin, steroid, triterpenoid, flavonoid, saponin, antrakuinon dan alkaloid (Kasolo, Bimenya, Ojok, \& Ochieng, 2010). Sashidhara et al., (2009) melaporkan bahwa daun kelor memiliki aktivitas sebagai antiinflamasi, antioksidan, antitumor, antialergi, antiviral, dan antiangiogenik.

Beberapa peneliti menyatakan bahwa senyawa flavonoid diduga efektif dalam menghambat pembentukan asam urat dan bersifat antiinflamasi serta analgetik. Hal ini disebabkan karena flavonoid dapat menghambat aktivitas enzim xantin oksidase melalui interaksi dengan enzim tersebut pada gugus samping dan mekanisme inhibisi kompetitif. Secara in-vitro beberapa senyawa flavonoid dapat menghambat enzim xantin oksidase diantaranya flavonoid, luteolin, apigenin, kuersetin dan miresetin (Muthadi,
Retnani, \& Wahyuningtyas, 2012; Kristinawati \& Nurlaela, 2013; Rinayanti, Rahayu, \& Syachfitri, 2016).

\section{METODE PENELITIAN}

\section{Alat dan bahan}

Alat-alat yang digunakan dalam penelitian ini, yaitu alat-alat kaca, kanula, Nesco®ulticheck Uric Acid, restainer tikus, seperangkat alat maserasi, strip test Uric Acid, timbangan analitik, dan timbangan hewan. Bahan-bahan yang digunakan dalam penelitian ini, yaitu aluminium foil, allopurinol, betadin, daun kelor (Moringa oleifera L.), etanol 96\%, kapas, kalium oksonat, kertas saring, larutan Na-CMC 1\%, larutan fisiologi $\mathrm{NaCl}$ 0,9\% dan makanan standar tikus.

\section{Pengambilan dan Pengolahan Sampel}

Sampel yang digunakan dalam penelitian ini adalah daun kelor dikumpulkan dan dicuci bersih dengan air mengalir. Kemudian dilakukan perajangan atau sampel dipotongpotong kecil, lalu dikeringkan dengan cara diangin-anginkan pada ruang terbuka tanpa terkena sinar matahari langsung. Setelah kering, sampel dihaluskan (Kemenkes RI, 2010).

\section{Ekstraksi Sampel}

Simplisia daun kelor ditimbang sebanyak 300 g lalu dimasukkan ke dalam wadah maserasi. Setelah itu ditambahkan pelarut etanol 96\% sebanyak $3000 \mathrm{~mL}$ (1:10). Simplisia direndam selama 6 jam pertama sambil diaduk sesekali, kemudian didiamkan 
selama 18 jam. Setelah itu disaring dan ampasnya diremaserasi sebanyak dua kali dengan jenis dan jumlah pelarut yang sama. Hasil penyarian yang diperoleh selanjutnya diuapkan hingga diperoleh ekstrak etanol kental (Kemenkes RI, 2010).

\section{Pengujian Aktivitas Penurunan Kadar} Asam Urat

\section{Pembuatan suspensi Alluporinol $5 \mathrm{mg} / \mathrm{kgBB}$}

Tablet alluporinol ditimbang sebanyak 20 tablet, dan dihitung berat rata-ratanya. Setelah itu tablet digerus dan dilarutkan dengan larutan Na-CMC 1\% hingga $10 \mathrm{~mL}$.

\section{Pembuatan Kalium Oksonat $250 \mathrm{mg} / \mathrm{kg}$ BB}

Kalium Oksonat ditimbang sebanyak 750 mg. Digerus dalam lumpang dan ditambahkan larutan Na-CMC 1\%, kemudian dimasukkan dalam gelas kimia, lalu volume dicukupkan sampai $30 \mathrm{~mL}$ (Tao Yi, Li, Xue Su, FangDong, \& Fu Li, 2012).

Pembuatan suspensi ekstrak etanol daun kelor

Suspensi ekstrak etanol daun kelor akan dibuat dengan dosis 70, 140, dan 280 $\mathrm{mg} / \mathrm{kgBB}$. Pembuatan suspensi dilakukan dengan cara ditimbang ekstrak etanol daun kelor secara berturut-turut 70, 140 dan 280 mg. Kemudian ditambahkan larutan Na-CMC $1 \%$ dan dihomogenkan. Setelah itu, dituang ke dalam labu ukur $10 \mathrm{~mL}$ dan dicukupkan dengan larutan Na-CMC 1\% sampai tanda batas (Tao Yi, Li, Xue Su, FangDong, \& Fu Li, 2012).

\section{Perlakuan hewan uji}

Tikus yang telah diadaptasikan selanjutnya dipuasakan selama 8-16 jam kemudian ditimbang berat badannya. Sebelum diberi perlakuan, semua hewan uji diukur kadar asam urat darah sebagai kadar awal (normal). Seluruh hewan uji dibuat hiperurisemia dengan diberikan jus hati ayam dan kalium oksonat $250 \mathrm{mg} / \mathrm{kgBB}$ secara oral. Satu jam kemudian dilakukan pengambilan darah hewan uji untuk diukur kadar asam uratnya sebagai kadar asam urat induksi. Selanjutnya hewan uji dibagi dalam 5 kelompok yaitu : Kelompok I tanpa pemberian obat (Kontrol negatif); Kelompok II diberikan allopurinol dengan dosis $5 \mathrm{mg} / \mathrm{kgBB}$ (kontrol positif); Kelompok III, IV dan V diberikan ekstrak etanol daun kelor dengan dosis 70, 140 dan $280 \mathrm{mg} / \mathrm{kgBB}$. Jus hati ayam diberikan secara oral selama 7 hari berturut-turut dan kalium oksonat $250 \mathrm{mg} / \mathrm{kgBB}$ pada hari ke-7, kecuali kelompok I kontrol negatif juga diberikan kalium oksonat hari ke-1. Kalium oksonat diberikan 1 jam setelah pemberian jus hati ayam. Allopurinol dan ekstrak etanol daun kelor diberikan pada hewan coba secara oral selama 7 hari berturut-turut 1 jam setelah pemberian jus hati ayam atau kalium oksonat. Satu jam setelah pemberian obat terakhir pada hari ke-7 dilakukan pengukuran kadar kadar asam urat terapi tikus (kadar asam urat akhir) (Tao Yi, Li, Xue Su, FangDong, \& Fu Li, 2012; Hongyan, Suling, Weina, Yajie, \& Jie, 2016). 
Kadar Asam urat pada tikus putih (Rattus norvegicus) diukur melalui pengambilan darah lewat ekor tikus. Dalam waktu 20 detik pada layar akan tertera kadar asam urat dalam mg/dL. Uji dilakukan pada setiap tikus pada semua kelompok.

\section{HASIL DAN PEMBAHASAN}

Penelitian ini bertujuan untuk menguji adanya potensi ekstrak etanol daun kelor dalam menurunan kadar asam urat pada tikus putih yang diinduksi kalium oksonat. Daun kelor adalah salah satu tanaman yang biasanya digunakan oleh masyarakat untuk menangani beberapa penyakit, seperti penyakit antiinflamasi, antialergi, antifertilitas dan berkhasiat sebagai antimikroba (Krisnadi, 2015).

Tahap awal yang dilakukan dalam penelitian ini adalah melakukan penyiapan sampel daun kelor yang akan digunakan. Penyiapan sampel terdiri dari pengumpulan, pengeringan dan diserbukkan. Sampel yang telah diserbukkan sebanyak 300 g kemudian diekstraksi dengan metode maserasi menggunakan pelarut etanol 96\%.

Hewan coba yang digunakan adalah tikus putih. Sebelum dilakukan pengujian hewan coba diukur kadar asam urat awalnya terlebih dahulu. Pengukuran kadar asam urat dilakukan menggunakan alat pengukur kadar asam urat dan stripnya. Kadar asam urat normal tikus galur wistar adalah 1,2 - 7,5 mg/dL (Mitruka \& Rawnsley., 1977). Kemudian hewan coba dibagi menjadi lima kelompok, yaitu kelompok I kontrol negatif, kelompok II diberi alluporinol $5 \mathrm{mg} / \mathrm{KgBB}$, dan kelompok III, IV dan V yang diinduksi dengan ekstrak etanol daun kelor dengan dosis berturut-turut $70, \quad 140$, dan 280 $\mathrm{mg} / \mathrm{KgBB}$ yang sudah diukur kadar asam urat awal. Pemilihan dosis dari ekstrak etanol daun kelor yang digunakan merupakan hasil konversi dosis dari penelitian yang dilakukan Sulistyawati \& Pratiwi (2016), tentang pengaruh pemberian ekstrak etanol daun kelor terhadap aktivitas analgesik dan antiinflamasi pada mencit.

Hewan coba diinduksikan menggunakan jus hati ayam secara oral selama 7 hari yang bertujuan untuk mendapatkan kondisi hiperurisemia. Pada hari ke 7, 1 jam setelah jus hati ayam diberikan, kalium oksonat diberikan secara intraperitonial (Krisdayanti, Hajrah, \& Ramadhan, 2016). Kalium oksonat merupakan penghambat enzim urikase secara kompetitif, yang menghambat efek enzim urikase hati dan memproduksi asam urat secara berlebih di dalam darah pada hewan coba seperti tikus. Jika enzim urikase telah dihambat, maka kadar asam urat akan meningkat sehingga bisa digunakan sebagai penginduksi hiperurisemia (Dira \& Harmely., 2014).

Kontrol positif yang digunakan dalam penelitian ini adalah Allopurinol yang merupakan obat sintetik yang biasanya dikonsumsi oleh masyarakat untuk menurunkan kadar asam urat. Allopurinol merupakan analog purin yang bekerja dengan 
Tabel 1. Rata-rata pengukuran kadar asam urat pada hewan coba tikus putih awal, induksi, dan setelah terapi.

\begin{tabular}{cccc}
\hline \multirow{2}{*}{ Kelompok perlakuan } & \multicolumn{3}{c}{ Rata-Rata Pengukuran Kadar Asam Urat } \\
& \multicolumn{3}{c}{ Img/dL) } \\
\cline { 2 - 4 } & Awal & Induksi & Terapi \\
\hline I Kalium Oksonat $250 \mathrm{mg} / \mathrm{KgBB}$ & $3,9 \pm 0,26$ & $12,83 \pm 2,02$ & $13,86 \pm 0,66$ \\
\hline II Kontrol Positif (Allopurinol 5 mg/KgBB) & $4,27 \pm 0,96$ & $9,23 \pm 1,13$ & $4,16 \pm 1,00$ \\
\hline III (EEDK 70 mg/KgBB) & $3,56 \pm 0,05$ & $12,33 \pm 4,31$ & $4,23 \pm 0,23$ \\
\hline IV (EEDK 140 mg/KgBB) & $3,76 \pm 0,57$ & $11,57 \pm 3,13$ & $3,3 \pm 0,28$ \\
\hline V (EEDK 280 mg/KgBB) & $3,3 \pm 0,25$ & $13,67 \pm 2,65$ & $3,67 \pm 0,98$ \\
\hline
\end{tabular}

Keterangan:

EEDK : Ekstrak Etanol Daun Kelor

menghambat aktivitas dari enzim xantin oksidase, enzim yang mengkatalisis dua langkah terakhir pada sintesis asam urat (Tao Yi, Li, Xue Su, FangDong, \& Fu Li, 2012).

Pengukuran dilakukan 1 jam setelah pemberian kalium oksonat sebagai kadar asam urat induksi. Setelah 1 jam pemberian kalium oksonat terjadi peningkatan kadar asam urat melebihi kadar asam urat normal. Hal ini menunjukkan bahwa induksi hiperurisemia yang dilakukan berhasil. Pemberian kalium oksonat diberikan pada hari ke 7 setelah pemberian jus hati ayam selama 7 hari berturut-turut. Sedangkan Allopurinol dan ekstrak etanol daun kelor diberikan pada hewan coba secara oral 1 jam setelah pemberian saripati ayam selama 7 hari dan kalium oksonat pada hari ke 7. Perlakuan dilakukan selama 14 hari karena berdasarkan pada penelitian Tao Yi L et al. (2012). Selanjutnya setelah pemberian obat dan ekstrak pada hari ke 7 dilakukan pengukuran kadar asam urat terapi tikus (kadar asam urat akhir). Data pengukuran yang diperoleh selanjutnya dianalisi untuk melihat perbandingan kadar asam urat awal, induksi, dan terapi. Hasil rata-rata pengukuran kadar asam urat awal, induksi dan terapi pada tikus putih dapat dilihat pada tabel 1 .

Data berdasarkan tabel 1 menunjukkan peningkatan kadar asam urat setelah pemberian jus hati ayam dan kalium oksonat pada semua kelompok. Pada kelompok II kontrol positif allopurinol, kelompok ekstrak etanol daun kelor dengan dosis 70, 140, dan $280 \mathrm{mg} / \mathrm{KgBB}$ mengalami penurunan kadar asam urat dibandingkan dengan kelompok I yang diberikan kalium oksonat mengalami peningkatan kadar asam urat. Kemudian dihitung rata-rata persen penurunan kadar asam urat yang dapat dilihat pada tabel 2 .

Data pada tabel 2 menunjukkan bahwa kelompok ekstrak etanol daun kelor dosis 280 $\mathrm{mg} / \mathrm{KgBB}$ memiliki rata-rata persen penurunan kadar asam urat paling tinggi dibandingkan dengan kelompok ekstrak etanol daun kelor dosis 70 dan 140 $\mathrm{mg} / \mathrm{KgBB}$, serta kelompok kontrol positif allopurinol. Sedangkan pada kelompok kontrol negatif mengalami peningkatan kadar asam urat. Hal ini berarti ekstrak etanol daun kelor dengan dosis 70, 140, dan 280 
Tabel 2. Rata-rata persen penurunan kadar asam urat induksi-terapi pada tikus.

\begin{tabular}{c|c}
\hline Kelompok Perlakuan & Rata-rata persen penurunan kadar asam urat (\%) \\
\hline I Kalium Oksonat 250 mg/KgBB & $-9,44$ \\
II Kontrol Positif Allopurinol & 54,11 \\
III EEDK 70 mg/KgBB & 63,20 \\
IV EEDK 140 mg/KgBB & 69,44 \\
V EEDK 280 mg/KgBB & 72,53 \\
\hline
\end{tabular}

Keterangan

(-) Menunjukkan adanya peningkatan kadar asam urat EEDK : Ekstrak Etanol Daun Kelor

$\mathrm{mg} / \mathrm{KgBB}$ mampu menurunkan kadar asam urat dengan nilai persen penurunan yang tinggi dibandingkan dengan kelompok kontrol positif allopurinol dan kelompok jus hati ayam dan kalium oksonat $250 \mathrm{mg} / \mathrm{KgBB}$.

Berdasarkan penelitian yang telah dilakukan dapat diketahui bahwa ekstrak etanol daun kelor dengan dosis 70, 140, dan $280 \mathrm{mg} / \mathrm{KgBB}$ dapat memberikan pengaruh dalam menurunkan kadar asam urat tikus putih kembali ke kadar normal. Hal ini dikarenakan sampel ekstrak etanol daun kelor memiliki kandungan salah senyawa flavonoid yaitu kuersetin. Beberapa penelitian menyebutkan bahwa senyawa kuersetin dapat menginhibisi terbentuknya asam urat dengan cara menghambat aktivitas dari enzim xantin oksidase melalui mekanisme campuran (kompetitif atau nonkompetitif (Zhang, Wang, Zhang, \& Gong, 2018). Selain itu penelitian ini sejalan dengan sejalan dengan penelitian Rahmawati \& Candra (2015) bahwa seduhan daun kelor pada dosis 3,75 $\mathrm{g} / \mathrm{kg}$ dapat menurunkan kadar asam urat tikus putih yang diinduksi dengan otak kambing (Rahmawati \& Kusumastuti, 2015).

\section{KESIMPULAN}

Hasil penelitian menunjukkan bahwa ekstrak etanol daun kelor memiliki potensi menurunkan kadar asam urat tikus putih dengan dosis efektif sebesar 70, 140 dan 280 $\mathrm{mg} / \mathrm{KgBB}$.

\section{DAFTAR PUSTAKA}

Cendrianti, F., Muslichah, S., \& Ulfa, E. U. (2014). Uji Aktivitas Antihiperurisemia Ekstrak n-Heksana, Etil Asetat, dan Etanol 70\% Daun Tempuyung (Sonchus arvensis L.) pada Mencit Jantan Hiperurisemia. EJurnal Pustaka Kesehatan, 2(2), 205-210.

Dira, \& Harmely. (2014). Uji Aktivitas Antihiperurisemia Ekstrak Etanol Sambiloto (Androgravis paniculata Nees), Brotowali (Tinospora crispa (L.) Hook. \& Thomson), Manggis (Garcinia mangostana L.), Lada Hitam (Piper nigrum L.) dan Jahe Merah (Zingiber officinale Rosc.) secara In Vitro (Skripsi). Semarang: Fakultas Farmasi Universitas Diponegoro.

Herliana, E. (2013). Penyakit Asam Urat Kandas Berkat Herbal. Jakarta : Agromedia Pustaka.

Hongyan, L., Suling, W., Weina, Z., Yajie, Z., \& Jie, R. (2016). Antihyperuricemic Effect of Liquiritigenin in Potassium Oxonate-Induced Hyperuricemic Rats. Biomed Pharmacother, 84, 1930-1936.

Kasolo, J. N., Bimenya, G. S., Ojok, L., \& Ochieng, J. (2010). Phytochemicals and Uses of Moringa oleifera Leaves in Uganda Rural Communities. J Med Plant Res, 4(9), 753-757. 
Kemenkes RI. (2010). Suplemen I Farmakope Herbal Indonesia. Jakarta: Kementerian Kesehatan Republik Indonesia.

Krisdayanti, L., Hajrah, H., \& Ramadhan, A. M. (2016). Uji Aktivitas Antihiperuresemia Ekstrak Etanol Biji Salak (Salacca zalacca) Terhadap Tikus Putih Jantan Galur Wistar (Ratus novergicus) yang Diinduksi Kalium Oksonat. Proceeding of Mulawarman Pharmaceuticals Conferences (pp. 187192). Samarinda: Mulawarman Pharmaceuticals Conferences.

Krisnadi, A. (2015). Kelor Super Nutrisi. Blora: Kelorina.

Kristinawati, \& Nurlaela. (2013). Pengaruh Pemberian Filtrat Buah Kelor (Moringa oliefera) terhadap Kadar Asam Urat pada Hewan Coba Tikus Putih (Rattus norvegicus) Strain Wistar. Media Bina Ilmiah, 7(6), 27-32.

Misnadiarly. (2007). Rematik: Asam UratHiperurisemia Arthritis Gout Edisi 1. Jakarta: Pustaka Obor Populer.

Mitruka, \& Rawnsley. (1977). Clinical Biochemical and Hematological Reference Value in Normal Experimental Animals. USA: University of California.

Muthadi, Retnani, I., \& Wahyuningtyas, N. (2012). Penghambatan Xantin Oksidase Oleh Kombinasi Ekstrak Tempuyung (Sonchusrrvensis) dan Salam (Syzygium polyanthum) pada Mencit Hiperurisemia. Biomedika, 4(10), 17-22.

Rahmawati, \& Kusumastuti, A. (2015). Pengaruh Pemberian Seduhan Daun Kelor (Moringa oleifera L.) dalam Menurunkan Kadar Asam Urat Tikus Putih (Rattus norvegicus). Journal of Nutrition College, 4(4), 593-598.
Rinayanti, A., Rahayu, S., \& Syachfitri, R. (2016). Uji Aktivitas Penghambatan Xantin Oksidase secara In-Vitro oleh Isolat 6,4'-Dihidroksi-4-Metoksibenzofenon - 2 - O - $\beta$ - D Glukopiranosida (C20H22O10) yang Diisolasi dari Mahkota Dewa (Phaleria macrocarpa (Scheff.) Boerl). Phatm Sci Res, 3(1), 1-11.

Sashidhara, K., Rosaiah, J., Tyagi, E., Shukla, R., Raghubir, R., \& Rajendran, S. (2009). Rare Dipeptide and Urea Derivatives From Roots of Moringa oleifera as Potential Anti-Inflammatory and Antinociceptive Agents. Eur J Med Chem, 44(1), 432-6.

Silbernagl, S., \& Lang, F. (2000). Color Atlas of Pathophysiology. New York: Thieme Flexibook.

Suhendi, A., Nurcahyanti, Muhtadi, \& Sutrisna, E. M. (2011). Aktivitas Antihiperurisemia Ekstrak Jinten Hitam (Coleus ambonicus Iour) pada Mencit Jantan Galur Balb-C dan Standarisasinya. Indonesian Journal of Pharmacy, 22(2), 77-84.

Sulistyawati, R., \& Pratiwi, P. Y. (2016). Pengaruh Pemberian Ekstrak Etanol Daun Kelor (Moringa oleifera L.) Terhadap Aktivitas Analgesik dan Antiinflamasi Melalui Ekspresi Enzim Siklooksigenase. Pharmaciana, 6(1), 31-38.

Tao Yi, L., Li, J., Xue Su, D., FangDong, J., \& Fu Li, C. (2012). Hypouricemic Effect of The Methanol Extract From Prunus mume Fruit in Mice. Pharm Biol, 50(11), 1423-7.

Zhang, C., Wang, R., Zhang, G., \& Gong, D. (2018). Mechanistic insights into the inhibition of quercetin on xanthine oxidase. Int J Biol Macromol., 112, 405412. 